\title{
Choriogonadotropin Subunit Beta 3
}

National Cancer Institute

\section{Source}

National Cancer Institute. Choriogonadotropin Subunit Beta 3. NCI Thesaurus. Code C17479.

Choriogonadotropin subunit beta 3 (165 aa, $18 \mathrm{kDa}$ ) is encoded by the human CGB3, CGB5, and CGB8 genes. This protein is involved in the regulation of steroid synthesis during pregnancy. 